\title{
MAESTROS, ARTESANOS, INTELECTUALES
}

De Tezanos Araceli. Maestros, Artesanos Intelectuales. Bogotá, Universidad Pedagógica Nacional, Centró de Investigaciones - CIUP, Centro Internacional de Investigaciones para el Dcsarrollo CIID,1987, $211 \mathrm{P}$.

Aracelli de Tezanos desarrolló durante su permanencia en el país una línea de investigaciones que tuvo por objeto mostrar la realidad de la escuela primaría en Colombia. Como consecuencia de ese "mirar la escuela" surgió la necesidad de indagar por la formación de maestros de enseñanza primaria, estudiando y analizando su currículo, desentrañando los modelos pedagógicos que sustentan su formación, indagando por la imagen de su profesión con el intéres de postular algunas indicaciones encaminadas a lograr un mejor maestro.

Es ese el sentido de Maestros Artesanos Intelectuales. El texto pone de presente la crisis dc la formación de maestros en Colombia, los cuales a partir del decreto 1419 de 1978 no se titulan como tales sino como Bachilleres Pedagógicos. Ingresan a la docencia por la facilidad de acceder al mercado de trabajo y para tener una base a partir de la cual estudiar, posteriormente, una carrera "propiamente universitaria".

En el campo de la formación de docentes se vive, como sucede en casi todo el terreno de lo educativo, un desfase entre lo escrito y lo analizado en los documentos oficiales y aquello que evidencia la práctica real y cotidiana. Los formadores de docentes repiten los mismos vicios de la escuela primaria y lo que ofrecen como modelo pedagógico a sus alumnos sólo son "maneras de dictar clase". Lejos están los modelos de los grandes pedagogos y sólo en la estructura de la hora de clase es posible recordar el esquema de la "lección"tal como fue postulada por Herbart o Pestalozzi.

El libro consta de ocho capítulos que van desde la justificación del estudio hasta una propuesta alternativa para la formación de maestros, pasando por un análisis crítico de la escuela normal y sus programas, lo vocacional, lo práctico y lo teórico en la formación de maestros, y la sustentación de la tesis del estudio que alude al modelo de la formación de artesanos en la edad media.

El texto está construido de tal suerte que evidencie lo opuesto y lo contradictorio, la incongruencia entre el documento oficial y el quehacer del formador de docentes, entre el programa y la entrevista.

La autora, no sólo presenta estas contradicciones, sino que emprende la búsqueda de los orígenes de las mismas y reconstruye las causas de "las maneras de dictar clase", comunes a la normal y a la escuela primaria.

Gloria Calvo. 